\title{
Recent advances in the biogeochemistry of nitrogen in the ocean
}

\author{
S. W. A. Naqvi ${ }^{1}$, M. Voss $^{2}$, and J. P. Montoya ${ }^{3}$ \\ ${ }^{1}$ National Institute of Oceanography (Council of Scientific and Industrial Research), Dona Paula, Goa 403 004, India \\ ${ }^{2}$ Leibniz Institute for Baltic Sea Research, Seestrasse 15, 18119 Rostock, Germany \\ ${ }^{3}$ School of Biology, Georgia Institute of Technology, Atlanta GA 30332, USA
}

Received: 24 January 2008 - Published in Biogeosciences Discuss.: 7 March 2008

Revised: 24 June 2008 - Accepted: 26 June 2008 - Published: 24 July 2008

Until fairly recently, study of the marine nitrogen cycle was considered to be important but a bit dull. Important because nitrogen had long been recognized as an essential nutrient that often limits primary production in the ocean but dull because the residence time of fixed nitrogen in the ocean was believed to be long ( $10000 \mathrm{yr}$; Emery et al., 1955), and its budget, like those of most other elements, at or very near steady state. Serious efforts to quantify the key terms in the combined nitrogen budget - denitrification and nitrogen fixation - began in the 1970s, and despite varying estimates provided by different investigators, the notion of a steady state began to be challenged in the mid-1980s (Codispoti and Christensen, 1985, and references therein). The discovery of large glacial-interglacial changes in atmospheric carbon dioxide content based on analyses of polar ice cores (Delmas et al., 1980), arguably one of the most important findings in Earth Sciences in recent years, left paleoclimatologists scrambling for an explanation, and one of the earliest hypotheses offered invoked changes in the fixed nitrogen inventory of the oceans (McElroy, 1983), subsequently refined by Altabet et al. (1995) and Ganeshram et al. (1995). However, the extent to which variations in denitrification or nitrogen fixation can drive changes in nitrogen inventory (Falkowski, 1997) that contribute to climatic cycles, and whether or not the nitrogen budget in today's ocean is balanced, are issues that remain unsettled (Sigman and Boyle, 2000; Codispoti et al., 2001; Gruber, 2004).

The interest in the balance (or lack thereof) between the input and loss terms of the oceanic nitrogen budget has led to a broad range of studies including focused biological measurements of specific processes (e.g., $\mathrm{N}_{2}$-fixation and denitrification), basin-scale geochemical measurements, and integrative modeling (Gruber and Sarmiento, 1997; Brandes et

\section{Correspondence to: S. W. A. Naqvi} (naqvi@nio.org) al., 1998; Brandes and Devol, 2002; Deutsch et al., 2004, 2007; Sigman et al., 2005; Devol et al., 2006), and consequently marked improvements in flux estimates. Recent research on the nitrogen cycle has also uncovered new players and processes on both the supply and demand sides of the nitrogen cycle (Brandes et al., 2007). The rapidly increasing application of molecular tools during the last two decades has provided new insights into the composition and structure of various microbial communities involved in the nitrogen cycle (Zehr and Ward, 2002; Ward, 2005). For example, on the supply side, DNA sequence analysis has revealed a diverse community of $\mathrm{N}_{2}$ fixing organisms in coastal and oceanic waters (Zehr et al., 1998; Zehr et al., 2001; Falcon et al., 2004), many of which have not been isolated. Some of these recently discovered $\mathrm{N}_{2}$ fixers show very high rates of $\mathrm{N}_{2}$ fixation in the water column and we are only now developing an appreciation for their importance in supplying combined nitrogen to the ocean through studies that integrate molecular and biogeochemical techniques (Montoya et al., 2004; Zehr et al., 2007). Another important discovery made in the last few years is that Archaea, among the most abundant microbial groups in the ocean, are important contributors to nitrification that was previously believed to be carried out only by bacteria (Francis et al., 2007; Beman et al, 2008, and references therein).

Perhaps the most important recent finding on the demand side is the discovery of anaerobic ammonium oxidation (anammox), a dissimilatory process involving reaction of ammonia with nitrite (Strous et al., 1999). Anammox provides an additional pathway of conversion of fixed nitrogen to the relatively inert elemental form $\left(\mathrm{N}_{2}\right)$. The occurrence of anammox in marine sediments was first reported by Thamdrup and Dalsgaard (2002) whereas in the water column this process was first detected in enclosed basins (Dalsgaard et al., 2003; Kuypers et al., 2003). Evidence for its importance in the open-ocean oxygen minimum zones (OMZs) has since been mounting (Kuypers et al., 2005; Thamdrup et al., 2006;

Published by Copernicus Publications on behalf of the European Geosciences Union. 
Hamersley et al., 2007; Nicholls et al., 2007). In fact, in almost all of the open-ocean studies, anammox has been found to be the dominant process with significant heterotrophic denitrification rates measured only in a few cases (Thamdrup et al., 2006; Nicholls et al., 2007). This is surprising because nitrite used for anammox should be largely derived from dissimilatory nitrate reduction, although a coupling between nitrification and anammox has also been reported from the upper portion of the Black Sea suboxic zone (Lam et al., 2007). Whether or not the apparent lack of further reduction of nitrite to $\mathrm{N}_{2}$ by heterotrophic denitrifiers is real and as widespread as these recent reports suggest, or it is a methodological artifact, still remains to be established. There is certainly no dearth of microbes genetically equipped to undertake denitrification in the oceanic suboxic zones (Jayakumar et al., 2004; Castro-Gonzales et al., 2005), and if this process is truly as unimportant as most of the incubation results suggest, then the mechanisms and pathways of organic matter degradation in these zones becomes a very important question. In contrast, both anammox and heterotrophic denitrification have been found to be important in sediments (Thamdrup and Dalsgaard, 2002; Dalsgaard and Thamdrup, 2002; Trimmer et al., 2006), with the latter playing a dominant role in eutrophic coastal regions (Thamdrup and Dalsgaard, 2002). Recently, intracellular accumulation of nitrate and complete denitrification to $\mathrm{N}_{2}$ has been reported for the benthic foraminifer Globobulimina pseudospinescens (RisgaardPetersen et al., 2006), one of the few eukaryotes known to be capable of denitrification.

Additional modes of loss of fixed nitrogen could also occur through reactions of nitrate (or nitrite) with other reduced chemical species, although their quantitative importance is probably much smaller. Reactions involving reduced metal species (primarily $\mathrm{Mn}^{2+}$ and $\mathrm{Fe}^{2+}$ ) are thermodynamically feasible and can be coupled to metal reduction reactions to drive denitrification with no net consumption of metal ions (Luther et al., 1997), but conclusive evidence for their occurrence in the environment is lacking so far.

Several studies have shown that a number of sulphur bacteria (e.g. Thioploca, Beggiatoa and Thiomargarita) accumulate high concentrations of nitrate within their vacuoles when at the sediment-water interface, then migrate downward through the sedimentary redox gradient to access sulphide, which they oxidize with their intracellular store of nitrate (Fossing et al., 1995; Schulz et al., 1999). This behaviour results in injection of oxidant much deeper into the sediment column than could be reached by diffusive fluxes alone. It was first thought that nitrate was converted to $\mathrm{N}_{2}$ by these bacteria (Fossing et al., 1995), but subsequent research has established ammonium to be the end product (Otte et al., 1999; Preisler et al., 2007). This processes (dissimilatory nitrate reduction to ammonium, DNRA), of course, does not cause a loss of combined nitrogen, although ammonium produced may subsequently be used for anammox.
The oceanic cycling of nitrous oxide has received considerable attention in recent years. The oceans have long been recognized as a net source of this potent greenhouse gas, and while oceanic nitrous oxide efflux is not a very significant term in the combined nitrogen budget, it constitutes at least one-third of input of nitrous oxide to the atmosphere from all sources. Most previous studies of nitrous oxide had focused on the open ocean, which led to an underestimation of the oceanic source term (Bange, 2006). Not only are the fluxes of nitrous oxide from coastal waters higher, but the processes responsible for its production also appear to be different from those in the open ocean in that denitrification can sometimes produce large amounts of $\mathrm{N}_{2} \mathrm{O}$ in shallow suboxic waters (Naqvi et al., 2000; Bange et al., 2001).

Human activities have impacted global nitrogen cycle to a very large extent. Production of synthetic fertilizers, fossil fuel combustion, and cultivation of leguminous crops have approximately doubled the input of combined nitrogen to the terrestrial nitrogen cycle, and the supply of fixed nitrogen to the sea in all probability has also undergone a similar enhancement since the Industrial Revolution (Galloway et al., 2004). The business-as-usual projections for future terrestrial nitrogen loading to coastal ecosystems paint a bleak picture (Seitzinger et al., 2002). As it is, eutrophication is causing expansion and intensification of low-oxygen zones in coastal areas all over the world affecting redox transformations of nitrogen (Naqvi et al., 2000; Diaz, 2001; Chen et al., 2007). One of the likely consequences of this phenomenon is the development of additional 'hotspots' for nitrous oxide production in the coastal ocean, such as that observed over the western Indian continental shelf (Naqvi et al., 2000). This, together with the expansion of open-ocean OMZs (Stramma et al., 2008), implies that the oceanic budget of nitrous oxide may be substantially altered by anthropogenic infringement.

It is apparent from the above overview that the marine nitrogen cycle is more dynamic (with the turnover time of fixed nitrogen now believed to be $\sim 1,500 \mathrm{yr}$; Codispoti et al., 2001), less well understood, and much more exciting than previously thought. However, despite impressive and rapid advances in our understanding of many important aspects of the marine nitrogen cycle, there are a number of fundamental issues that remain unresolved. Therefore, a broad synthesis of the current state of our knowledge is both timely and necessary as it would serve as a tool for channeling future research efforts in the right direction. Keeping this in view, we organized an international workshop, "Significant Processes, Observations, and Transformation in Oceanic Nitrogen (SPOT-ON)" at the Institute for Baltic Sea Research, Warnemünde, Germany, from June 26 to 1 July 2005. Sponsored by the Deutsche Forschungsgemeinschaft (DFG), the overarching goal of SPOT-ON was to delineate the major current uncertainties and gaps in our fundamental understanding of the oceanic nitrogen cycle. The workshop was organized around a series of major themes, with invited and contributed 
papers in each area. Some of the papers presented at the Workshop have already been published elsewhere (e.g., Devol et al., 2006; Johnson et al., 2006; Moisander et al., 2006; Paerl et al., 2006; Thamdrup et al., 2006; Westley et al., 2006; Brunelle et al., 2007; Casciotti and McIlvin, 2007; Deutsch et al., 2007; Hamersley et al., 2007; Yamagishi et al., 2007). The remaining papers, which deal with diverse aspects of the nitrogen cycle are included in this issue. Here we provide a brief overview of some of the major highlights of SPOT-ON, with particular reference to papers published in this volume.

\section{Theme: the global $\mathrm{N}$ cycle}

The oceanic fixed nitrogen balance (or the lack thereof), continues to be a topic of intense debate. As in Codispoti et al. (2001), Codispoti (2007) argues for a high rate of fixed nitrogen loss $\left(\sim 400 \mathrm{Tg} \mathrm{N} \mathrm{yr}^{-1}\right)$ from today's oceans, a view again contested by Gruber (2006) and Sarmiento (2006) in their reviews of this manuscript. Among other things, Codispoti bases his high estimate on measurements of $\mathrm{N}_{2} / \mathrm{Ar}$ ratios in oxygen minimum zones, which should reflect the total production of $\mathrm{N}_{2}$ via denitrification, but Gruber questions the general applicability of these results. Sarmiento, on the other hand, considers the sedimentary denitrification rate estimate arrived at by Codispoti to be too high.

One major point of contention is the relative importance of sedimentary and water column denitrification. Brandes and Devol (2002) proposed an isotopic approach to partition denitrification between the sediments and the water column based on the observation that denitrification in the water column involves much greater expression of isotopic fractionation than sedimentary denitrification. Using the observed mean nitrogen isotopic composition of nitrate in the ocean $(\sim 5 \%$ o) Brandes and Devol showed that the ratio between sedimentary and water column denitrification should be $~ 3.5: 1$. However, Deutsch et al. (2004) pointed out that since the oceanic waters are not well mixed and denitrification and $\mathrm{N}_{2}$-fixation are dominant in well-defined and often different geographical areas, the dilution effect will lower this ratio to $<3$. Altabet (2007) further argues that due to other factors (conversion of organic $\mathrm{N}$ to $\mathrm{N}_{2}$, Rayleigh closed and open system effects) the effective discrimination factor for denitrification in the water column is only about half of its inherent microbial value, and so the sedimentary to water column ratio should be even lower. The application of this ratio in constraining the total oceanic denitrification thus seems to have limitations. There is also a possibility, as Codispoti points out, that the water column denitrification rates in today's ocean, based as they are on observations made only over the past few decades, could also have been enhanced by human activities. Should this be the case then the isotopic signal would not have propagated throughout the ocean, and hence one cannot constrain the total oceanic denitrification rate from the current isotopic composition of nitrate in the ocean.

There were several papers dealing with modeling presented at the SPOT-ON Workshop including the one by Deutsch et al. (2007) that made use of the distribution of $P^{*}$ (a tracer similar to the $\mathrm{N}^{*}$ introduced by Gruber and Sarmiento, 1997) to estimate $\mathrm{N}_{2}$-fixation rates in the ocean. A major conclusion of this study is that the zones of $\mathrm{N}_{2-}$ fixation and denitrification are not geographically separated, as has been believed so far (Gruber and Sarmiento, 1997). This is because denitrification creates an excess of phosphate that should stimulate $\mathrm{N}_{2}$ fixation. This linkage is not always apparent, however, as shown by the North Atlantic, which accounts for only a small fraction of the global water-column denitrification but has long been recognized as a major region of $\mathrm{N}_{2}$-fixation. Mills et al. (2004) found co-limitation of $\mathrm{N}_{2}$-fixation in this region by $P$ and iron. As another modeling component of SPOT-ON, Coles and Hood (2007) utilize a coupled physical-biogeochemical model that explicitly includes $P$ and iron dynamics (in addition to nitrogen cycling) to simulate $\mathrm{N}^{*}$ distribution in the North Atlantic. The model can reproduce the large scale $\mathrm{N}^{*}$ anomaly patterns but requires a high $\mathrm{N}_{2}$ fixation rate $\left(3.4 \times 10^{12}\right.$ moles $\mathrm{N} \mathrm{yr}^{-1}$ between Lats. $25^{\circ} \mathrm{S}$ to $65^{\circ} \mathrm{N}$ ). Coles and Hood argue for an upward revision of $\mathrm{N}_{2}$ fixation rate estimate for the ocean in order to help resolve the apparent imbalances in the global nitrogen budget.

\section{Theme: supply of $\mathbf{N}$ to the ocean}

Jickells (2006) provides a comprehensive review of the available information on atmospheric deposition of various forms of nitrogen over the ocean, and the effects of this deposition on the marine environment both in coastal and offshore areas. Jickells demonstrates that, due to anthropogenic enhancement, atmospheric inputs to the ocean are now comparable with riverine fluxes of dissolved inorganic nitrogen. This paper also examines the management strategies required to reduce atmospheric nitrogen loading, emphasizing different strategies for ammonia/ammonium and nitric acid/nitrate, with the former requiring local regulation but the latter necessitating a regional approach.

$\mathrm{N}_{2}$ fixation is the most important source of combined $\mathrm{N}$ to the ocean, and a number of papers focused on this process. Ohlendieck et al. (2007) present results of new measurements of $\mathrm{N}_{2}$-fixation rates with concomitant estimates of primary production for two summers in the Baltic Sea that indicate a somewhat larger contribution of $\mathrm{N}_{2}$-fixation to new production than previously believed. Large geographical and interannual variability observed in this study appears to be driven by temperature and vertical stratification. Analyses of $\mathrm{N}_{2}$ fixation rates by various size classes of diazotrophs reveal that organisms $>5 \mu \mathrm{m}$ in size account for most of the $\mathrm{N}_{2}$ fixation. The C:N ratios of these diazotrophs are higher 
than the Redfield values, but ratios in filamentous bacterial cells were a little lower indicating either carbon release by the diazotrophs or additional uptake of regenerated nitrogen.

Most of the research on $\mathrm{N}_{2}$-fixation in the ocean has focused on larger organisms, especially the filamentous, colonial Trichodesmium that forms extensive and striking blooms in the tropics and subtropics. However, recent work has highlighted the potential importance of unicellular diazotrophs (Zehr et al., 2001; Montoya et al., 2004). Montoya et al. (2007) investigate relative contributions of Trichodesmium and such smaller organisms to diazotrophy in the tropical Atlantic Ocean using previously published and new data. Their results reveal significant and systematic differences between the eastern and western regions with Trichodesmium dominating diazotrophy in the west and the unidentified small organisms becoming more important in the east, with the overall nitrogen fixation rate being more or less invariable zonally. However, the cause of the observed trend remains to be investigated.

A number of articles concentrate on specific issues related to $\mathrm{N}_{2}$ fixation. Based on laboratory cultures of Trichodesmium grown at different temperatures, Breitbarth et al. (2007) show that the typical correlation of Trichodesmium abundance with ambient water temperature arises primarily from the direct physiological effects of temperature on the growth of this genus. Combining their results with the model-derived change in sea surface temperatures (SSTs) for the future, the authors predict a reduction of $\mathrm{N}_{2}$ fixation by Trichodesmium due to global warming. However, it is unclear how the overall rate of $\mathrm{N}_{2}$ fixation will be affected by climate change because other ambient environmental factors may change as well, and the sensitivity of other diazotrophic organisms to temperature is not known at present.

Mulholland (2007) reviews the literature on the fate of new nitrogen fixed by the diazotrophs. The key question she addresses is whether the carbon and nitrogen fixed by diazotrophs contribute to "new" or "regenerated" production? She summarizes the current knowledge of diazotrophic $\mathrm{N}_{2}$ and $\mathrm{C}$ fixation, nitrogen and carbon release and the trophic interactions with special emphasis on Trichodesmium.

\section{Theme: losses of $\mathbf{N}$ from the ocean}

With regard to losses of fixed nitrogen from the sea, in addition to the above-mentioned studies on anammox from the suboxic zones of the eastern tropical Pacific and Atlantic, a large amount of information has come from the Arabian Sea, which houses the other major oceanic suboxic zone. Naqvi et al. (2006) combine previously published data with new measurements to show the contrasts between the perennial openocean suboxic zone and the volumetrically smaller but more intense suboxic zone that develops seasonally over the western Indian shelf. One of the most interesting observations from the former region is the large mismatch between the excess $\mathrm{N}_{2}$ computed from the measured $\mathrm{N}_{2} / \mathrm{Ar}$ ratio and the Redfield stoichiometry-based nitrate deficits (the latter being lower by a factor of 2). Anammox can account for only a part of this discrepancy and other factors (e.g. anaerobic degradation of non Redfieldian organic matter, presumably arising from $\mathrm{N}_{2}$ fixation) must also be important (Devol et al., 2006).

$\mathrm{N}_{2} \mathrm{O}$ cycling is the subject of two articles by Walter and co-workers, the first from the North Atlantic and the second from the Baltic Sea. The North Atlantic data set presented by Walter et al. (2006a) is perhaps the most detailed and extensive collected from this region so far, enabling the preparation of basin-wide $\mathrm{N}_{2} \mathrm{O}$ distribution maps at several isopycnal horizons. The trends of variability observed match expectations with the highest subsurface concentrations occurring in the eastern part of the tropical basin, and $\Delta N_{2} \mathrm{O}$ (difference between the observed and saturation values) covarying with the apparent oxygen utilization and nitrate. Observations in the Baltic (Walter et al., 2006b) were made about nine months after an inflow event from the North Sea had occurred in January 2003. This intrusion carried oxygen to the otherwise anoxic subsurface waters of the Baltic, and produced a patchwork of redox environments in the region, ranging from fully oxic to anoxic, and consequently large spatial variability in $\mathrm{N}_{2} \mathrm{O}$ concentration. $\mathrm{N}_{2} \mathrm{O}$ concentrations observed at the peripheries of the suboxic zone in the Baltic are much lower than those observed in the open ocean suboxic zones. A similar trend is also observed in the Black Sea (Westley et al., 2006), indicating a different balance between $\mathrm{N}_{2} \mathrm{O}$ production and consumption in these enclosed basins.

There has been considerable debate in the literature about the threshold oxygen concentration needed for the onset of denitrification. While experiments using bacterial cultures (e.g. Körner and Zumft, 1989) and sediments (Bonin and Raymond, 1990) showed that dissimilatory nitrate reduction could occur at oxygen concentration as high as $\sim 150 \mu \mathrm{M}$, the secondary nitrite maximum in the oceanic OMZs has been generally found to be confined to oxygen $<1 \mu \mathrm{M}$ when measurements were made with the colorimetric procedure suitable for the low-oxygen environments (Cline and Richards, 1972; Morrison et al., 1999; Codispoti et al., 2001) In-situ measurements using oxygen electrodes within suboxic zones of the eastern tropical South Pacific and Arabian Sea indicate that the actual concentrations are even lower (G. Lavik, personal communication). This threshold value is the same as that proposed by Richards (1971), but it is slightly lower than the "critical oxygen concentrations" (1.2-3.8, mean $2.4 \mu \mathrm{M})$ experimentally determined by Devol (1978) for bacteria isolated from the eastern tropical North Pacific and Saanich Inlet. Values from the latter system were on the upper side of the above range, consistent with significant nitrite concentrations occurring at oxygen levels up to $4 \mu \mathrm{M}$. While the oxygen threshold is arguably different for various bacteria (Körner and Zumft, 1989), the question remains: why are bacteria capable of 'aerobic denitrification' restrained in the oceanic OMZs? 
The volume of seawater with dissolved oxygen content marginally above the above-mentioned threshold (i.e. in the $1-10 \mu \mathrm{M}$ range) is much larger than the volume of the suboxic zones identified by the secondary nitrite maximum. This means that large fluctuations in water column denitrification rate are not only possible but very likely to occur on a short term basis. One remarkable example is provided by the Bay of Bengal where the minimum oxygen concentration is $2-$ $3 \mu \mathrm{M}$. Absence of vigorous denitrification in this region is reflected by the absence of a secondary nitrite maximum and much higher $(\times 2)$ nitrate concentration within the core of the OMZ (200-300 m) as compared to the central Arabian Sea (Rao et al., 1994). This region thus only requires a very slight change in the existing balance between oxygen consumption and renewal to become denitrifying. How quickly the feedback mechanisms (e.g. enhanced $\mathrm{N}_{2}$ fixation) can respond to such changes is not known. However, if the large imbalance between the losses and inputs estimated by Codispoti (200-400 $\mathrm{Tg} \mathrm{N} \mathrm{yr}^{-1}$ ) persists, it should show up in highresolution sedimentary $\delta^{15} \mathrm{~N}$ records. Altabet (2007) uses a simple model to demonstrate that changing water column denitrification by $\pm 30 \%$ or $\mathrm{N}_{2}$ fixation by $\pm 15 \%$ produces $>1 \%$ o shifts in average oceanic $\delta^{15} \mathrm{~N}$ on the time scale of nitrogen turnover in the ocean. Altabet also examines high resolution $\delta^{15} \mathrm{~N}$ records from several sites considered to be sensitive to oceanic average $\delta^{15} \mathrm{~N}$ and finds no detectable change over the last 3000 years, implying a balanced marine nitrogen budget through the latest Holocene. This would imply that either the losses of nitrogen from the ocean have increased in recent times or, as noted above, we continue to underestimate the global rate of $\mathrm{N}_{2}$-fixation in the ocean despite the upward revision from $25 \mathrm{Tg} \mathrm{N} \mathrm{yr}^{-1}$ (Codispoti and Christensen, 1985) to $135 \mathrm{Tg} \mathrm{N} \mathrm{yr}^{-1}$ (Codispoti, 2007) over the last two decades.

\section{Theme: human impact and controls on the $\mathrm{N}$ cycle}

Voss et al. (2006) use extensive data sets on chemical and dual stable isotopic composition of nitrate in several rivers draining into the Baltic Sea to identify the sources of nitrate in the river systems. Estimates of source attribution by emission models, Global Land Cover models and isotope mixing models are compared.

The Baltic, of course, is one of the regions where the $\mathrm{N}$ cycle has been clearly and substantially altered by human activities. R. Elmgren's talk at the SPOT-ON meeting dealt with the complex nature of such impact arising from the riverine loading of $\mathrm{N}$ and $P$ loss of $\mathrm{N}$ due to denitrification in deep waters and associated mobilization of $P$ that, in turn, favours blooms of diazotrophs such as Aphanizomenon (Rolff et al., 2007; Moisander et al., 2007). In such a system, countering eutrophication would involve strong reductions of external and, if possible, internal loads of both $P$ and N. Similar reductions of nutrient loading were also rec- ommended by H. Paerl in his presentation that focused on effects of anthropogenic and climatic perturbations on nutrientphytoplankton interactions and eutrophication in the Chesapeake Bay and the Neuse River Estuary, two highly eutrophied estuarine systems along the US East Coast (Paerl et al., 2006).

\section{Theme: methodological advances}

Presentations under this theme included development of new sensors and their application (Johnson et al., 2006), isotopomer measurements on $\mathrm{N}_{2} \mathrm{O}$ (Westley et al., 2006; Yamagishi et al., 2007) and several others involving application of molecular techniques.

Given the difficulty involved in culturing microbes that mediate various biogeochemical transformations including redox reactions of the $\mathrm{N}$ cycle, molecular tools have been found to be extremely useful to gain insights into the structure, functions and capabilities of these organisms (Zehr and Ward, 2002). There is a rapidly expanding database on phylogenetic diversity of natural denitrifying communities in both sediments and water column (e.g. Braker et al., 2000; Jayakumar et al., 2004). Falk et al. (2007) compare denitrifying microbial communities across environmental gradients within the water column and coastal sediments of the Baltic Sea by employing one of the two nitrite reductase genes, nirS, as a molecular marker for denitrifiers. Phylogenetic analysis of nirS genes from the Baltic Sea and of sequences from other areas indicate distinct denitrifier communities that seem to group mostly according to their habitats. They conclude that distinct marine nirS-type denitrifier communities developed after selection determined by their habitats, the ambient environmental conditions and isolation by large geographic distances between habitats.

P. Moisander reported on the development of a nifH oligonucleotide microarray that includes most of the known nifH sequences from various marine environments. The diazotrophic community structure in microbial mats from Guerrero Negro, Baja California, Mexico, has been studied using polymerase chain reaction amplification of the nifH gene and the nifH oligonucleotide microarray (Moisander et al., 2006). This allows comparison of relative numbers of the gene and transcripts of the dominant nitrogen-fixing taxa for determining the relative abundances and gene expression of each taxa.

Until very recently, dissolved organic nitrogen (DON) had been largely neglected as a potentially-important source of nitrogen for phytoplankton because of smaller variability relative to the inorganic fixed nitrogen pool. This view is now being revised as a result of development of newer techniques including the application of ${ }^{15} \mathrm{~N}$ tracers. Bronk et al. (2007) present a synthesis of the rapidly accumulating evidence for the bioavailability of DON. While diatoms appear largely to utilize nitrate, other eukaryotic phytoplankton use reduced nitrogen forms and low molecular weight DON such as urea, 
amino acids and peptides. This review also provides an account of the enormous progress made in the molecular aspects of DON cycling, including the identification and characterization of functional genes encoding for key enzymes involved.

\section{Theme: evolution and diversity of the $\mathrm{N}$ cycle}

Although several talks were presented under this theme, including one by J. Brandes on the prebiotic and protobiotic origins of the global $\mathrm{N}$ cycle, and a number of others based on paleo-studies using stable isotope tracers (e.g. Brunelle et al., 2007), there is only one article included in this issue. The diazotrophic cyanobacteria are among the most ancient photoautotrophs. An example of their varying abundance in the geological past in response to environmental changes is provided by Ohkouchi et al. (2006). These authors determined the isotopic composition of the bulk sediment as well as geoporphyrins from the Livello Bonarelli black shale deposited during the Cretaceous Oceanic Anoxic Event 2 (OAE-2, ca. $94 \mathrm{Ma}$ ). Their results suggest that diazotrophic cyanobacteria were the major primary producers during the OAE-2, and probably also during similar events that intermittently occurred throughout the later half of the Earth's history.

Acknowledgements. We thank the DFG and US National Science Foundation for sponsoring the SPOT-ON Workshop, and to all contributors to make it successful. We express our sincere gratitude to Jack Middelburg for his patient and efficient handling as an editor of a large number of manuscripts submitted for this special issue.

Edited by: J. Middelburg

\section{References}

Altabet, M. A.: Constraints on oceanic N balance/imbalance from sedimentary ${ }^{15} \mathrm{~N}$ records, Biogeosciences, 4, 75-86, 2007 , http://www.biogeosciences.net/4/75/2007/.

Altabet, M. A., François, R., Murray, D. W., and Prell, W. L.: Climate-related variations in denitrification in the Arabian Sea from sediment ${ }^{15} \mathrm{~N} /{ }^{14} \mathrm{~N}$ ratios, Nature, 373, 506-509, 1995.

Bange, H. W., Andreae, M. O., Lal, S., Law, C. S., Naqvi, S. W. A., Patra, P. K., Rixen, T., and Upstill-Goddard, R. C.: Nitrous oxide emissions from the Arabian Sea: A synthesis, Atmos. Chem. Phys., 1, 61-71, 2001,

http://www.atmos-chem-phys.net/1/61/2001/.

Bange, H. W.: New directions: The importance of oceanic nitrous oxide emissions, Atmos. Environ., 40, 198-199, 2006.

Beman, J. M., Popp, B. N., and Francis, C. A.: Molecular and biogeochemical evidence for ammonia oxidation by marine Crenarchaeota in the Gulf of California, ISME J., 2, 429-441, 2008.

Braker, G., Zhou, J. Z., Wu, L. Y., Devol, A. H., and Tiedje, J. M.: Nitrite reductase genes (nirK and nirS) as functional markers to investigate diversity of denitrifying bacteria in Pacific northwest marine sediment communities, Appl. Environ. Microbiol., 66, 2096-2104, 2000.

Brandes, J. A., and Devol, A. H.: A global marine-fixed nitrogen isotopic budget: Implications for Holocene nitrogen cycling, Global Biogeochem. Cy., 16, 1120, doi:10.1029/2001GB001856, 2002.

Brandes, J. A., Devol, A. H., and Deutsch, C.: New developments in the marine nitrogen cycle, Chem. Rev., 107, 577-589, 2007.

Brandes, J. A., Devol, A. H., Yoshinari, T., Jayakumar, A., and Naqvi, S. W. A.: Isotopic composition of nitrate in the central Arabian Sea and eastern tropical North Pacific: A tracer for mixing and nitrogen cycles, Limnol. Oceanogr., 43, 1680-1689, 1998.

Bonin, P. and Raymond, N.: Effects of oxygen on denitrification in marine sediments. Hydrobiologia, 207, 115-122, 1990.

Breitbarth, E., Oschlies, A., and LaRoche, J.: Physiological constraints on the global distribution of Trichodesmium - effect of temperature on diazotrophy, Biogeosciences, 4, 53-61, 2007, http://www.biogeosciences.net/4/53/2007/.

Bronk, D. A., See, J. H., Bradley, P., and Killberg, L.: DON as a source of bioavailable nitrogen for phytoplanton, Biogeosciences, 4, 283-296, 2007,

http://www.biogeosciences.net/4/283/2007/.

Brunelle, B. G., Sigman, D. M., Cook, M. S., Keigwin, L. D., Haug, G. H., Plessen, B., Schettler, G., and Jaccard, S. L.: Evidence from diatom-bound nitrogen isotopes for subarctic $\mathrm{Pa}$ cific stratification during the last ice age and a link to North Pacific denitrification changes, Paleoceanography, 22, PA1215, doi:10.1029/2005PA001205, 2007.

Casciotti, K. L. and McIlvin, M. R.: Isotopic analyses of nitrate and nitrite from reference mixtures and application to Eastern Tropical North Pacific waters, Mar. Chem., 107, 184-201, 2007.

Castro-Gonzalez, M., Braker, G., Farias, L., and Ulloa, O.: Communities of nirS-type denitrifiers in the water column of the oxygen minimum zone in the eastern South Pacific, Environ. Microbiol., 7, 1298-1306, 2005.

Chen, C. C., Gong, G. C., and Shiah, F. K.: Hypoxia in the East China Sea: One of the largest coastal low-oxygen areas in the world, Mar. Environ. Res., 64, 399-408, 2007.

Cline, J. D. and Richards, F. A.: Oxygen deficient conditions and nitrate reduction in the eastern tropical North Pacific Ocean, Limnol. Oceanogr., 17, 885-900, 1972.

Codispoti, L. A. and Christensen, J. P.: Nitrification, denitrification and nitrous oxide cycling in the eastern tropical South Pacific Ocean, Mar. Chem., 16, 277-300, 1985.

Codispoti, L. A., Brandes, J. A., Christensen, J. P., Devol, A. H., Naqvi, S. W. A., Paerl, H. W., and Yoshinari, T.: The oceanic fixed nitrogen and nitrous oxide budgets: Moving targets as we enter the anthropocene? Sci. Mar., 65, 85-105, 2001.

Codispoti, L. A.: An oceanic fixed nitrogen sink exceeding 400 $\mathrm{TgNa}^{-1}$ vs the concept of homeostasis in the fixed-nitrogen inventory, Biogeosciences, 4, 233-253, 2007, http://www.biogeosciences.net/4/233/2007/.

Coles, V. J. and Hood, R. R.: Modeling the impact of iron and phosphorus limitations on nitrogen fixation in the Atlantic Ocean, Biogeosciences, 4, 455-479, 2007, http://www.biogeosciences.net/4/455/2007/.

Dalsgaard, T. and Thamdrup, B.: Factors controlling anaerobic am- 
monium oxidation with nitrite in marine sediments, Appl. Environ. Microbiol., 68, 3802-3808, 2002.

Dalsgaard, T., Canfield, D. E., Petersen, J., Thamdrup, B., and Acuna-Gonzalez, J.: $\mathrm{N}_{2}$ production by the anammox reaction in the anoxic water column of Golfo Dulce, Costa Rica, Nature, 422, 602-608, 2003.

Delmas, R. J., Ascencio, J. -M., and Legrand, M.: Polar ice evidence that atmospheric $\mathrm{CO}_{2} 20000 \mathrm{yr} \mathrm{BP}$ was $50 \%$ of present, Nature, 284, 155-57, 1980.

Deutsch, C., Sigman, D. M., Thunell, R. C., Meckler, A. N., and Haug, G. H.: Isotopic constraints on glacial/interglacial changes in the oceanic nitrogen budget, Global Biogeochem. Cy., 18, 4013, doi:10.1029/2003GB002189, 2004.

Deutsch, C., Sarmiento, J., Sigman D. M., Gruber, N., and Dunne, J.: Spatial coupling of nitrogen inputs and losses in the ocean, Nature, 445, 163-167, 2007.

Devol, A. H.: Bacterial oxygen uptake kinetics as related to biological processes in the oxygen deficient zones of the oceans, Deep-Sea Res., 25, 137-146, 1978.

Devol, A. H., Uhlenhopp, A. G., Naqvi, S. W. A., Brandes, J. A., Jayakumar, A., Naik, H., Gaurin, S., Codispoti, L. A., and Yoshinari, T.: Denitrification rates and excess nitrogen gas concentrations in the Arabian Sea oxygen deficient zone, Deep-Sea Res. I, 53, 1533-1547, 2006.

Diaz, R. J.: Overview of hypoxia around the world, J. Environ. Qual., 30, 275-281, 2001.

Emery, K. O., Orr, W. L., and Rittenberg, S. C.: Nutrient budgets in the ocean, in: Essays in Natural Sciences in Honor of Captain Allan Hancock, University of Southern California Press, Los Angeles, pp. 299-309, 1955.

Falcon, L. I., Carpenter, E. J., Cipriano, F., Bergman, B., and Capone, D. G.: $\mathrm{N}_{2}$ fixation by unicellular bacterioplankton from the Atlantic and Pacific Oceans: Phylogeny and in situ rates, Appl. Environ. Microbiol., 70, 765-770, 2004.

Falk, S., M. Hannig, M., Gliesche, C., Wardenga, R., Köster, M., Jürgens, K., and Braker, G.: nirS-containing denitrifier communities in the water column and sediment of the Baltic Sea, Biogeosciences, 4, 255-268, 2007,

http://www.biogeosciences.net/4/255/2007/.

Falkowski, P. G.: Evolution of the nitrogen cycle and its influence on the biological sequestration of $\mathrm{CO}_{2}$ in the ocean, Nature, 387 , 272-275, 1997.

Fossing, H, Gallardo, V. A., Huttel, M., Nielsen, L. P., Schulz, H., Canfield, D. E., Forster, S., Glud, R. N., Gundersen, J. K., Kuver, J., Ramsing, N. B., Teske, A., Thamdrup, B., and Ulloa, O.: Concentration and transport of nitrate by the mat-forming sulphur bacterium Thioploca, Nature, 374, 713-715, 1995.

Francis, C. A., Beman, J. M., and Kuypers, M. M. M.: New processes and players in the nitrogen cycle: the microbial ecology of anaerobic and archaeal ammonia oxidation, ISME J., 1, 1927, 2007.

Galloway, J. N., Dentener, F. J., Capone, D. G., Boyer, E. W., Howarth, R. W., Seitzinger, S. P., Asner, G. P., Cleveland, C. C., Green, P. A., Holland, E. A., Karl, D. M., Michaels, A. F., Porter, J. H., Townsend, A. R., and Vorosmarty, C. J.: Nitrogen cycles: past, present and future, Biogeochemistry, 70, 153-226, 2004.

Ganeshram, R. S., Pedersen, T. F., Calvert, S. F., and Murray, J. W.: Large changes in oceanic nutrient inventories from glacial to interglacial periods, Nature, 376, 755-758, 1995.

Gruber, N.: The dynamics of the marine nitrogen cycle and its influence on atmospheric $\mathrm{CO}_{2}$, in: The Ocean Carbon Cycle and Climate, edited by: Follows, M. and Oguz, T., NATO ASI Series, Kluwer Academic, Dordrecht, 97-148, 2004.

Gruber, N.: Interactive comment on "An oceanic fixed nitrogen sink exceeding $400 \mathrm{TgNa}^{-1}$ vs. the concept of homeostasis in the fixed-nitrogen inventory" by Codispoti, L. A., Biogeosciences Discuss., 3, S368-S374, 2006.

Gruber, N., and Sarmiento, J. L.: Global patterns of marine nitrogen fixation and denitrification. Global Biogeochem. Cy., 11, 235266, 1997.

Hamersley, M. R., Lavik, G., Woebken, D., Rattray, J. E., Lam, P., Hopmans, E. C., Sinninghe Damsté, J. S., Krüger, S., Graco, M., Gutiérrez, D., and Kuypers, M. M. M.: Anaerobic ammonium oxidation in the Peruvian oxygen minimum zone, Limnol. Oceanogr. 52, 923-933, 2007.

Jayakumar, D. A., Francis, C. A., Naqvi, S. W. A., and Ward, B. B.: Diversity of nitrite reductase genes (nirS) in the denitrifying water column of the coastal Arabian Sea, Aquat. Microb. Ecol., 34, 69-78, 2004.

Jickels, T.: The role of air-sea exchange in the marine nitrogen cycle, Biogeosciences, 3, 271-280, 2006.

Johnson, K. S., Coletti, L. J., and Chavez, F. P.: Diel nitrate cycles observed with in situ sensors predict monthly and annual new production, Deep-Sea Res. I, 53, 561-573, 2006.

Körner, H., and Zumft, W. G.: Expression of denitrification enzymes in response to the dissolved oxygen level and respiratory substrate in continuous culture of Pseudomonas stutzeri, Appl. Environ. Microbiol., 55, 1670-1676, 1989.

Kuypers, M. M. M., Sliekers, A. O., Lavik, G., Schmid, M., Jørgensen, B. B., Kuenen, J. G., Sinninghe Damsté, J. S., Strous, M., and Jetten M. S. M.: Anaerobic ammonium oxidation by anammox bacteria in the Black Sea, Nature, 422, 608-611, 2003.

Kuypers, M. M. M., Lavik, G., Wöbken, D., Schmid, M., Fuchs, B. M., Amann, R., Jørgensen, B. B., and Jetten M. S. M.: Massive nitrogen loss from the Benguela upwelling system through anaerobic ammonium oxidation, Proc. Nat. Acad. Sci. USA, 102, 6478-6483, 2005.

Lam, P., Jensen, M. M., Lavik, G., McGinnis, D. F., Muller, B., Schubert, C. J., Amann, R., Thamdrup, B., and Kuypers, M. M. M.: Linking crenarchaeal and bacterial nitrification to anammox in the Black Sea, Proc. Natl. Acad. Sci. USA, 104, 7104-7109, 2007.

Luther, G. W., Sundby, B., Lewis, B. L., Brendel, P. J., and Silverberg, N.: Interactions of manganese with the nitrogen cycle: Alternative pathways to dinitrogen, Geochim. Cosmochim. Ac., 61, 4043-4052, 1997.

McElroy, M. B.: Marine biological controls on atmospheric $\mathrm{CO}_{2}$ and climate, Nature, 302, 328-329, 1983.

Mills, M. M., Ridame, C., Davey, M., LaRoche, J., and Geider, R. J.: Iron and phosphorus co-limit nitrogen fixation in the Eastern Tropical North Atlantic, Nature, 429, 292-294, 2004.

Moisander, P. H., Paerl, H. W., Dyble, J., and Sivonen, K.: Phosphorus limitation and diel control of nitrogen-fixing cyanobacteria in the Baltic Sea, Mar. Ecol. Progr. Ser., 345, 41-50, 2007.

Moisander, P. H., Shiue, L., Steward, G. F., Jenkins, B. D., Bebout, B. M., and Zehr, J. P.: Application of a nifH oligonucleotide microarray for profiling diversity of $\mathrm{N}_{2}$-fixing microorganisms 
in marine microbial mats, Environ. Microbiol., 8, 1721-1735, 2006.

Montoya, J. P., Holl, C. M., Zehr, J. P., Hansen, A., Villareal, T. A., and Capone, D. G.: High rates of $\mathrm{N}_{2}$ fixation by unicellular diazotrophs in the oligotrophic Pacific Ocean, Nature, 430, 1027-1031, 2004.

Montoya, J. P., Voss, M., and Capone, D. G.: Spatial variation in $\mathrm{N}_{2}$-fixation rate and diazotroph activity in the Tropical Atlantic, Biogeosciences, 4, 369-376, 2007, http://www.biogeosciences.net/4/369/2007/.

Morrison, J. M., Codispoti, L. A., Smith, S. L., Wishner, K., Flagg, C., Gardner, W. D., Gaurin, S., Naqvi, S. W. A., Manghnani, V., Prosperie, L., and Gundersen, J. S.: The oxygen minimum zone in the Arabian Sea during 1995, Deep-Sea Res. II, 46, 19031931, 1999.

Mulholland, M. R.: The fate of nitrogen fixed by diazotrophs in the ocean, Biogeosciences, 4, 37-51, 2007, http://www.biogeosciences.net/4/37/2007/.

Naqvi, S. W. A., Jayakumar, D. A., Narvekar, P. V., Naik, H., Sarma, V. V. S. S., D’Souza, W., Joseph, S., and George, M. D.: Increased marine production of $\mathrm{N}_{2} \mathrm{O}$ due to intensifying anoxia on the Indian continental shelf, Nature, 408, 346-349, 2000.

Naqvi, S. W. A., Naik, H., Pratihary, A., D’Souza, W., Narvekar, P. V., Jayakumar, D. A., Devol, A. H., Yoshinari, T., and Saino, T.: Coastal versus open-ocean denitrification in the Arabian Sea, Biogeosciences, 3, 621-633, 2006, http://www.biogeosciences.net/3/621/2006/.

Nicholls, J. C., Davies, C. A., and Trimmer, M.: High-resolution profiles and nitrogen isotope tracing reveal a dominant source of nitrous oxide and multiple pathways of nitrogen gas formation in the central Arabian Sea, Limnol. Oceanogr., 52, 156-168, 2007.

Ohlendieck, U., Gundersen, K., Meyerhfer, M., Fritsche, P., Nachtigall, K., and Bergmann, B.: The significance of nitrogen fixation to new production during early summer in the Baltic Sea, Biogeosciences, 4, 63-73, 2007, http://www.biogeosciences.net/4/63/2007/.

Ohkouchi, N., Kashiyama, Y., Kuroda, J., Ogawa, N. O., and Kitazato, H.: The importance of diazotrophic cyanobacteria as primary producers during Cretaceous Oceanic Anoxic Event 2, Biogeosciences, 3, 467-478, 2006, http://www.biogeosciences.net/3/467/2006/.

Otte, S., Kuenen, J. G., Nielsen, L. P., Paerl, H. W., Zopfi, J., Schulz, H. N., Teske, A., Strotmann, B., Gallardo, V. A., Jorgensen, B. B.: Nitrogen, carbon, and sulfur metabolism in natural Thioploca samples, Appl. Environ. Microbiol., 65, 3148-3157, 1999.

Paerl, H. W., Valdes, L. M., Peierls, B. L., Adolf, J. E., and Harding, L. W., Jr.: Anthropogenic and climatic influences on the eutrophication of large estuarine ecosystems, Limnol. Oceanogr., 51, 448-462, 2006.

Preisler, A., de Beer, D., Lichtschlag, A., Lavik, G., Boetius, A., and Jorgensen, B. B.: Biological and chemical sulfide oxidation in a Beggiatoa inhabited marine sediment, ISME J., 1, 341-353, 2007.

Rao, C. K., Naqvi, S. W. A., Kumar, M. D., Varaprasad, S. J. D., Jayakumar, D. A., George, M. D., and Singbal, S. Y. S.: Hydrochemistry of the Bay of Bengal: Possible reasons for a different watercolumn cycling of carbon and nitrogen from the Arabian Sea, Mar. Chem., 47, 279-290, 1994.

Richards, F. A.: Comments on the effect of denitrification on the budget of combined nitrogen in the ocean, Extrait de la mer, Bull. Soc. Franco-Japanaise d'Oceanographie, 9, 68-77, 1971.

Risgaard-Petersen, N., Langezaal, A. M., Ingvardsen, S., Schmid, M. C., Jetten, M. S. M., Op den Camp, H. J. M., Derksen, J. W. M., Pina-Ochoa, E., Eriksson, S. P., Nielsen, L. P., Revsbech, N. P., Cedhagen, T., and van der Zwaan, G. J.: Evidence for complete denitrification in a benthic foraminifer, Nature, 443, 93-96, 2006.

Rolff, C., Almesjo, L., and Elmgren, R.: Nitrogen fixation and abundance of the diazotrophic cyanobacterium Aphanizomenon sp in the Baltic Proper. Mar. Ecol. Progr. Ser., 332, 107-118, 2007.

Sarmiento, J.: Interactive comment on "An oceanic fixed nitrogen sink exceeding $400 \mathrm{TgNa}^{-1}$ vs the concept of homeostasis in the fixed-nitrogen inventory" by L. A. Codispoti, Biogeosciences Discuss., 3, S432-S440, 2006.

Schulz, H. N., Brinkhoff, T., Ferdelman, T. G., Marine, M. H., Teske, A., and Jørgensen, B. B.: Dense populations of a giant sulfur bacterium in Namibian shelf sediments, Science, 284, 493495, 1999.

Seitzinger, S. P., Kroeze, C., Bouwman, A. E., Caraco, N., Dentener, F., Styles, R. V.: Global patterns of dissolved inorganic and particulate nitrogen inputs to coastal systems, Estuaries, 25, 640-655, 2002.

Sigman, D. M., and Boyle, E. A.: Glacial/interglacial variations in atmospheric carbon dioxide, Nature, 407, 859-869, 2000.

Sigman D. M., Granger, J., DiFiore, P. J., Lehmann, M. M., Ho, R., Cane, G., and van Geen, A.: Coupled nitrogen and oxygen isotope measurements of nitrate along the eastern North Pacific margin, Global Biogeochem. Cy., 19, GB4022, doi:10.1029/2005GB002458, 2005.

Stramma, L., Johnson, G. C., Sprintall, J., and Mohrholz, V.: Expanding oxygen-minimum zones in the tropical oceans, Science, 320, 655-658, 2008.

Strous, M., Fuerst, J. A., Kramer, E. H. M., Logemann, S., Muyzer, G., Van de Pas-Schoonen, K. T., Webb, R., Kuenen, J. G., and Jetten, M. S. M.: Missing lithothroph identified as new planctomycete, Nature, 400, 446-449.

Thamdrup, B. and Dalsgaard, T.: Production of $\mathrm{N}_{2}$ through anaerobic ammonium oxidation coupled to nitrate reduction in marine sediments, Appl. Environ. Microbiol., 68, 1312-1318, 2002.

Thamdrup, B., Dalsgaard, T., Jensen, M. M., Ulloa, O., Farias, L., and Escribano, R.: Anaerobic ammonium oxidation in the oxygen-deficient waters off northern Chile, Limnol. Oceanogr., 51, 2145-2156, 2006.

Trimmer, M., Risgaard-Petersen, N., Nicholls, J. C., and Engstrom, P.: Direct measurement of anaerobic ammonium oxidation (anammox) and denitrification in intact sediment cores, Mar. Ecol. Prog. Ser., 326, 37-47, 2006.

Voss, M., Deutsch, B., Elmgren, R., Humborg, C., Kuuppo, P., Pastuszak, M., Rolff, C., and Schulte, U.: Source identification of nitrate by means of isotopic tracers in the Baltic Sea catchments, Biogeosciences, 3, 663-676, 2006, http://www.biogeosciences.net/3/663/2006/.

Walter, S., Bange, H. W., Breitenbach, U., and Wallace, D. W. R.: Nitrous oxide in the North Atlantic Ocean, Biogeosciences, 3, 607-619, 2006a, http://www.biogeosciences.net/3/607/2006/.

Walter, S., Breitenbach, U., Bange, H. W., Nausch, G., and Wallace, 
D. W. R.: Distribution of $\mathrm{N}_{2} \mathrm{O}$ in the Baltic Sea during transition from anoxic to oxic conditions, Biogeosciences, 3, 557-570, $2006 \mathrm{~b}$, http://www.biogeosciences.net/3/557/2006/.

Ward, B. B.: Molecular approaches to marine microbial ecology and the marine nitrogen cycle, Ann. Rev. Earth. Planet. Sci., 33, 301-333, 2005.

Westley, M. B., Yamagishi, H., Popp, B. N., and Yoshida, N.: Nitrous oxide cycling in the Black Sea inferred from stable isotope and isotopomer distributions, Deep-Sea Res. II, 53, 1802-1816, 2006.

Yamagishi, H., Westley, M. B., Popp, B. N., Toyoda, S., Yoshida, N., Watanabe, S., Koba, K., and Yamanaka, Y.: Role of nitrification and denitrification on the nitrous oxide cycle in the eastern tropical North Pacific and Gulf of California, J. Geophys. Res., 112, G02015, doi:10.1029/2006JG000227, 2007.
Zehr, J. P., Mellon, M. T., and Zani, S.: New nitrogen-fixing microorganisms detected in oligotrophic oceans by amplification of nitrogenase (nifH) genes, Appl. Environ. Microbiol., 64, 34443450, 1998.

Zehr, J. P., and Ward, B. B.: Nitrogen cycling in the ocean: New perspectives on processes and paradigms, Appl. Environ. Microbiol., 68, 1015-1024, 2002.

Zehr, J. P., Waterbury, J. B., Turner, P. J., Montoya, J. P., Omoregie, E., Steward, G. F., Hansen, A., and Karl, D. M.: New nitrogenfixing unicellular cyanobacteria discovered in the North Pacific Central Gyre, Nature, 412, 635-638, 2001.

Zehr, J. P., Montoya, J. P., Jenkins, B. D., Hewson, I., Mondragon, E., Short, C. M., Church, M. J., Hansen, A., and Karl, D. M.: Experiments linking nitrogenase gene expression to nitrogen fixation in the North Pacific subtropical gyre, Limnol. Oceanogr., 52, 169-183, 2007. 